\title{
The effects of glycerol on the metabolism and ultrastructure of boar spermatozoa
}

\author{
R. N. Murdoch and R. C. Jones \\ Department of Biological Sciences, University of Newcastle, New South Wales, 2308, Australia
}

\begin{abstract}
Summary. Cooling diluted boar semen to $5^{\circ} \mathrm{C}$ and the addition of glycerol at $20^{\circ} \mathrm{C}$ and $5^{\circ} \mathrm{C}$ all depressed the subsequent metabolism of glucose, but had no effect on total oxygen uptake or lactate production. Ultrastructural studies showed that although glycerol had no effect on middle-piece cytology, it increased the incidence of acrosomal vesiculation at $5^{\circ} \mathrm{C}$. It is concluded that acrosomal vesiculation does not affect the metabolism of spermatozoa and it is suggested that the reported detrimental effect of glycerol on the fertilizing capacity of spermatozoa is related to its membrane activity.
\end{abstract}

\section{Introduction}

During studies on deep-freezing of boar semen, Wilmut \& Polge (1974) found that storage in the presence of glycerol had a temperature-dependent effect on sperm fertilizing capacity. They showed that fertilization rates were reduced after semen was stored at $20^{\circ} \mathrm{C}$ in the presence of glycerol, but were much the same after storage in the presence or absence of glycerol at $5^{\circ} \mathrm{C}$. However, during storage in glycerol, there were no changes in the motility, morphology (Wilmut \& Polge, 1974), or ultrastructure (Jones, 1973b) of the spermatozoa which could be related to their loss of viability at $20^{\circ} \mathrm{C}$. To investigate further the action of glycerol, the present studies were carried out to determine its effects on the metabolism and ultrastructure of boar spermatozoa stored at $5^{\circ} \mathrm{C}$ and $20^{\circ} \mathrm{C}$ and then washed to remove the glycerol.

\section{Materials and Methods}

Whole semen was collected at a local piggery (Steggles Pty. Ltd, Benwerrin, New South Wales) from boars of proven fertility and strained through cotton gauze to remove any gelatinous material.

For the metabolic studies the experimental design (Table 1), diluent preparation and storage conditions were identical to those used by Jones (1973b; Exp. 4) except that, for technical reasons, the samples were stored in the presence of glycerol for 2 rather than $6 \mathrm{~h}$. The experiment is described in detail below because few methods were recorded in the previous report.

Seven $5 \mathrm{ml}$ samples were taken from each ejaculate. One sample ('fresh semen') was immediately centrifuged $(400 \mathrm{~g}$ for $5 \mathrm{~min}$ ) and the supernatant removed. The sperm pellet was washed twice in $5 \mathrm{ml} \mathrm{Ca}{ }^{2+}$-free Krebs-Ringer phosphate, pH 7.4 (Umbreit, Burris \& Stauffer, 1972), containing $30 \mathrm{mg}$ penicillin $/ 100 \mathrm{ml}$ and $50 \mathrm{mg}$ streptomycin $/ 100 \mathrm{ml}$, and suspended in an appropriate volume of the same diluent for the metabolic study. The other $5 \mathrm{ml}$ samples were diluted to $10 \mathrm{ml}$ with Trisglycine-egg yolk diluent (Wilmut \& Polge, 1974). Three samples were stored for $3 \mathrm{~h}$ at $20^{\circ} \mathrm{C}$, then diluted to $20 \mathrm{ml}$ with Tris-glycine-egg yolk diluent containing glycerol to produce concentrations of 0,5 or $10 \%(\mathrm{v} / \mathrm{v})$ glycerol. The samples were then stored for a further $2 \mathrm{~h}$ at $20^{\circ} \mathrm{C}$. The other three samples were cooled at $5^{\circ} \mathrm{C}$ over $3 \mathrm{~h}$, diluted with the glycerol-containing diluents and stored for a further $2 \mathrm{~h}$ at $5^{\circ} \mathrm{C}$. After storage, the samples were centrifuged and the sperm pellets washed twice and resuspended in the washing diluent in the same way as the samples of 'fresh semen'.

The metabolic studies began immediately after the samples were washed. The suspensions of spermatozoa $\left(0.5 \mathrm{ml} ; 5 \cdot 1-6.5 \times 10^{8}\right.$ cells/flask $)$ were incubated at $37^{\circ} \mathrm{C}$ for $3 \mathrm{~h}$ with $\mathrm{D}-\left[\mathrm{U}-{ }^{14} \mathrm{C}\right] \mathrm{glucose}$ (sp. act. $10 \mathrm{nCi} / \mu \mathrm{mol}$ : Radiochemical Centre, Amersham, England) in 6-ml capacity Warburg flasks containing $0.1 \mathrm{ml}$ of $20 \%(\mathrm{w} / \mathrm{v}) \mathrm{KOH}$ in the centre well. The radioactive glucose was added in $0.5 \mathrm{ml}$ of the $\mathrm{Ca}^{2+}$-free Krebs-Ringer phosphate to give a concentration of $10 \mu \mathrm{mol}(100 \mathrm{nCi}) / \mathrm{flask}$. Oxygen consumption was measured by using air as the gas phase. Glucose oxidation was determined 
by the measurement of ${ }^{14} \mathrm{CO}_{2}$ trapped in the $\mathrm{KOH}$ of the centre well. After the incubation period the $\mathrm{KOH}$ was washed with $0.8 \mathrm{ml}$ distilled water into a scintillation vial containing $10 \mathrm{ml}$ scintillation fluid and counted by liquid scintillation techniques. Aliquots of the sperm suspension were taken before and after incubation and deproteinized by the addition of 1 volume of $5 \%(\mathrm{w} / \mathrm{v}) \mathrm{ZnSO}_{4} \cdot 7 \mathrm{H}_{2} \mathrm{O}$ and 1 volume of $0.3 \mathrm{~N}-\mathrm{Ba}(\mathrm{OH})_{2}$. Glucose and lactate were assayed in the neutral filtrates by enzymic methods (Barker \& Britton, 1957; Huggett \& Nixon, 1957).

The ultrastructure of spermatozoa stored under conditions identical to those of the treatments described above was also examined. After incubation in the Warburg flasks for $1 \mathrm{~h}$ the spermatozoa were concentrated by centrifugation and prepared for transmission electron microscopy (Jones, 1973a, 1975). Low-power electron micrographs were scored (Jones, 1973b, 1975) according to whether the heads of spermatozoa were normal or showing stages of 'acrosomal vesiculation' or 'acrosomal vacuolation'. The tails were scored according to whether middle pieces were structurally normal or showed signs of cytolysis.

\section{Results}

Storage of boar spermatozoa for $5 \mathrm{~h}$ at 5 or $20^{\circ} \mathrm{C}$ in the presence or absence of glycerol significantly depressed the subsequent metabolism of glucose (Table 1). This effect was more pronounced following storage at $5^{\circ} \mathrm{C}$ than at $20^{\circ} \mathrm{C}$ particularly when measured by the amount of glucose oxidized and utilized. The addition of glycerol during storage at either temperature also depressed the subsequent oxidation and utilization of glucose but did not significantly affect the rate of oxygen consumption or lactate production.

Table 1. Metabolism of glucose by boar spermatozoa after storage at 5 and $20^{\circ} \mathrm{C}$ in the presence of various concentrations of glycerol

\begin{tabular}{lcccc}
\hline Treatment & $\begin{array}{c}\text { Oxygen } \\
\text { uptake } \\
(\mu \mathrm{l})\end{array}$ & $\begin{array}{c}\text { Glucose } \\
\text { oxidized } \\
(\mu \mathrm{mol})\end{array}$ & $\begin{array}{c}\text { Glucose } \\
\text { utilized } \\
(\mu \mathrm{mol})\end{array}$ & $\begin{array}{c}\text { Lactate } \\
\text { produced } \\
(\mu \mathrm{mol})\end{array}$ \\
\hline $\begin{array}{l}\text { (1) Fresh semen } \\
\text { Stored semen }\end{array}$ & 24.8 & 0.085 & 0.55 & 0.48 \\
(2) $20^{\circ} \mathrm{C}, 0 \%$ glycerol & 12.7 & 0.050 & 0.32 & 0.23 \\
(3) $20^{\circ} \mathrm{C}, 5 \%$ glycerol & 11.8 & 0.034 & 0.25 & 0.22 \\
(4) $20^{\circ} \mathrm{C}, 10 \%$ glycerol & 10.5 & 0.030 & 0.21 & 0.20 \\
(5) $5^{\circ} \mathrm{C}, 0 \%$ glycerol & 10.4 & 0.035 & 0.21 & 0.19 \\
(6) $5^{\circ} \mathrm{C}, 5 \%$ glycerol & 11.2 & 0.029 & 0.19 & 0.15 \\
(7) $5^{\circ} \mathrm{C}, 10 \%$ glycerol & 10.4 & 0.020 & 0.16 & 0.13
\end{tabular}

Values represent the means of replicates from 3 different boars and are calculated for $10^{8}$ spermatozoa per $3 \mathrm{~h}$.

Summary of the analyses of variance

\begin{tabular}{|c|c|c|c|c|c|}
\hline \multirow[b]{2}{*}{ Source of variation } & \multirow[b]{2}{*}{ d.f. } & \multicolumn{4}{|c|}{ Variance ratios } \\
\hline & & $\begin{array}{l}\text { Oxygen } \\
\text { uptake }\end{array}$ & $\begin{array}{l}\text { Glucose } \\
\text { oxidized }\end{array}$ & $\begin{array}{l}\text { Glucose } \\
\text { utilized }\end{array}$ & $\begin{array}{l}\text { Lactate } \\
\text { produced }\end{array}$ \\
\hline Fresh versus stored semen & 1 & $133.09^{* *}$ & $119 \cdot 88^{* *}$ & $275 \cdot 30^{* *}$ & $38 \cdot 80^{* *}$ \\
\hline (A) $20^{\circ} \mathrm{C}$ versus $5^{\circ} \mathrm{C}$ & 1 & $1 \cdot 22$ & $7.09^{*}$ & $23 \cdot 50^{* *}$ & 2.46 \\
\hline (B) Effect of glycerol & (2) & & & & \\
\hline (i) $0 \%$ versus the rest & 1 & 0.37 & $14 \cdot 00^{* *}$ & $17 \cdot 30^{* *}$ & 6.83 \\
\hline (ii) $5 \%$ versus $10 \%$ & 1 & 0.98 & $2 \cdot 41$ & $4 \cdot 40$ & 0.14 \\
\hline Interaction $\mathbf{A} \times \mathbf{B}$ & 2 & 0.58 & 0.60 & $1 \cdot 40$ & 0.08 \\
\hline Between boars & 2 & $6.47^{*}$ & 0.55 & $4 \cdot 50^{*}$ & 1.68 \\
\hline Residual & 12 & $3.60 \dagger$ & $0.000058 \uparrow$ & $0.0010 \uparrow$ & $0.0059 \dagger$ \\
\hline
\end{tabular}

${ }^{*} P<0.05 ;{ }^{* *} P<0.01$.

$\dagger$ Residual mean square. 
Ultrastructural examination of spermatozoa from Treatments 1, 2, 4, 5 and 7 (Table 1) showed that the responses were similar to those previously reported (Jones, 1973b). For the 'fresh semen' and samples stored at $20 \% \mathrm{C}$ in 0 and $10 \%$ glycerol and at $5 \% \mathrm{C}$ in 0 and $10 \%$ glycerol, the percentages of spermatozoa scored as possessing completely intact heads were, respectively, 91, 76, 75, 39 and 33; the corresponding percentages for completely intact middle pieces were 100, 88, 89, 96 and 98 . The structural changes to the heads of spermatozoa were mainly scored as stages of acrosomal vacuolation except for spermatozoa stored at $5^{\circ} \mathrm{C}$ in the presence of glycerol. In these samples, about $38 \%$ of spermatozoa were scored as undergoing acrosomal vesiculation.

\section{Discussion}

The ultrastructural findings described in this paper are consistent with those of previous work (Jones, 1973b) on the effects of temperature and glycerol on boar spermatozoa and confirm the occurrence of acrosomal vesiculation in the presence of glycerol at $5^{\circ} \mathrm{C}$. Furthermore, because there were no significant interactions between the effects of storage temperature and glycerol concentration in the analyses of variance of the metabolic data (Table 1), it is concluded that the occurrence of acrosomal vesiculation does not influence the metabolism of boar spermatozoa. Although lactate was a major end product of aerobic glycolysis, the relationship between lactate production and glucose utilization was not stoichiometric. This finding agrees with the observations of Nevo, Polge \& Frederick (1970).

In the present studies, the inclusion of glycerol in the Tris-glycine-egg yolk diluent depressed the subsequent utilization and oxidation of glucose without influencing the total oxygen uptake of the spermatozoa. Considering that glycerol also had no detectable effect on sperm motility or middle piece ultrastructure (Jones, 1973b; Wilmut \& Polge, 1974; present study), it is suggested that sufficient glycerol was taken up and retained (probably as a phosphorylated derivative) within the cells during storage and washing to compete with exogenous glucose as a substrate for utilization and oxidation (Mann \& White, 1957). Further, since glycerol is highly permeable to sperm membranes (Drevius, 1971) this argument explains why the metabolic studies showed no temperature-dependent effect of glycerol.

Regardless of how the metabolic studies are interpreted they provide no explanation of the reported temperature-dependent effect of glycerol on the fertilizing capacity of boar spermatozoa (Wilmut \& Polge, 1974). However, because glycerol cross-links lecithin membranes (Buckingham \& Staehelin, 1969) it is suggested that the polyol affects fertility by stabilizing the sperm membranes to an extent which reduces their capacity to undergo an acrosome reaction or to fuse with a vitelline membrane. Consequently, glycerol may have a more permanent action than do other compounds (e.g. inositol or 2-[N-morpholino]ethanesulphonic acid; Jones \& Martin 1976) which appear to stabilize sperm membranes during storage but destabilize them when removed by washing. To explain the increased occurrence of acrosomal vesiculation induced by adding glycerol at $5^{\circ} \mathrm{C}$, it is suggested that the acrosomal membrane becomes labile during cooling (Jones \& Martin, 1973) and subsequent cross-linking by glycerol favours the formation of vesicles.

This work was supported by a grant from the Australian Research Grants Committee.

\section{References}

BARKER, J.N. \& Britron, H.G. (1957) The enzymatic estimation of $\mathrm{L}(+)$ lactic acid. J. Physiol., Lond. 138, $3 P$.

Buckingham, J.H. \& Straehelin, L.A. (1969) The effect of glycerol on the structure of lecithin membranes; a study of freeze-etching and X-ray diffraction.J. Microsc. 90, 83-106.

Drevius, L.-O. (1971) Permeability coefficients of bull spermatozoa for water and polyhydric alcohols. Expl Cell Res. 69, 212-216.
Huggett, A. St. G. \& Nixon, D.A. (1957) Enzymic determination of blood glucose. Biochem.J. 66, $12 P$.

JoNES, R.C. (1973a) Preparation of spermatozoa for electron and light microscopy. J. Reprod. Fert. 33, 145-149.

JONES, R.C. (1973b) Changes occurring in the head of boar spermatozoa; vesiculation or vacuolation of the acrosome? J. Reprod. Fert. 33, 113-118.

JONES, R.C. (1975) Fertility and infertility in mammals in relation to sperm structure. In Biology of the Male Downloaded from Bioscientifica.com at 04/26/2023 08:59:15AM 
Gamete, pp. 343-365. Eds J. G. Duckett \& P. A. Racey. Academic Press, London.

JONES, R.C. \& MARTIN, I.C.A. (1973) The effects of dilution, egg-yolk and cooling to $5^{\circ} \mathrm{C}$ on the ultrastructure of ram spermatozoa. J. Reprod. Fert. 35, 311-320.

JONES, R.C. \& MARTIN, I.C.A. (1976) Some problems of evaluating semen quality. In Proc. Int. Sheep Breed. Conf., Muresk \& Perth, pp. 286-293. Eds G. J. Tomes, D. E. Robertson \& R. J. Lightfoot. W. Aust. Inst. Tech., Perth.
MaNN, T. \& WhITE, I.G. (1957) Glycerol metabolism by spermatozoa. Biochem.J. 65, 634-639.

Nevo, A.C., Polge, C. \& Frederick, G. (1970) Aerobic and anaerobic metabolism of boar spermatozoa in relation to their motility.J. Reprod. Fert. 22, 109-118.

UMbreIt, W.W., BlRRIS, R.H. \& STALFFER, J.F. (1972) Manometric and Biochemical Techniques Sth edn, p. 146. Burgess Publ. Co., Minneapolis.

WILMUT, I. \& Polge, C. (1974) The fertilizing capacity of boar semen stored in the presence of glycerol at 20, 5 and $-79^{\circ}$ C. J. Reprod. Fert. 38, 105-113.

Received 17 Aprll 1978 